\title{
Translating and Mapping the Many Voices in the Work of Niki Marangou
}

Marine Meunier

\section{(2) OpenEdition Journals}

Electronic version

URL: http://journals.openedition.org/transtexts/863

DOI: $10.4000 /$ transtexts.863

ISSN: 2105-2549

Publisher

Gregory B. Lee

Electronic reference

Marine Meunier, «Translating and Mapping the Many Voices in the Work of Niki Marangou », Transtext (e)s Transcultures 跨文本跨文化 [Online], 12 | 2017, Online since 10 July 2018, connection on 19 April 2019. URL : http://journals.openedition.org/transtexts/863 ; DOI : 10.4000/transtexts.863

This text was automatically generated on 19 April 2019

(c) Tous droits réservés 


\title{
Translating and Mapping the Many Voices in the Work of Niki Marangou
}

\author{
Marine Meunier
}

\section{Introduction: Languages in Context ${ }^{1}$}

1 Known to the world as a divided island caught between two "nations," Cyprus has since 1974 been bisected by the Green Line, a no man's land under the control of the United Nations that was erected in the aftermath of the Turkish military invasion of the northern part of the island. As a response to the coup ordered against President Makarios III by the Greek-Cypriot ultranationalist paramilitary EOKA B, Turkey invaded 37\% of the island's territory, under occupation until today. Forty percent of the total population was displaced by force, with the Greek-Cypriot population living north of the newly established partition line being moved to the south, and the Turkish-Cypriot population living in the south being moved to the north. ${ }^{2}$ Nicosia, the capital of Cyprus where the Green Line was first erected, has three accepted names-Lefkosia in Greek, Lefkosha in Turkish, and Nicosia in English. The city often stands as the symbol of the divided island: ${ }^{3}$

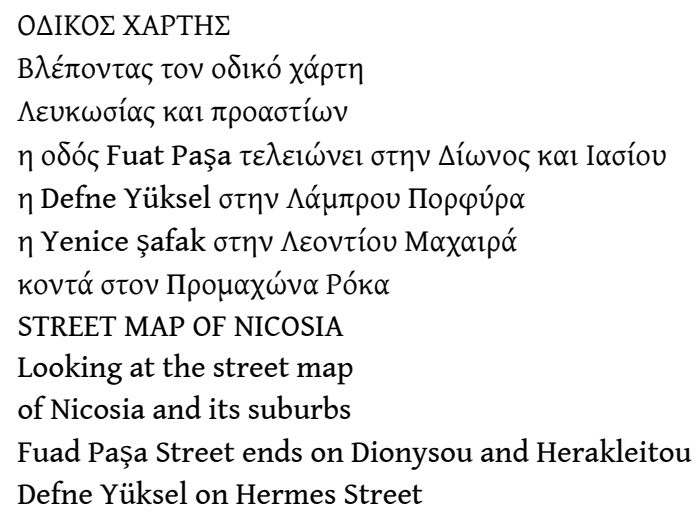


Yenice şafak on Leontiou Mahaira

close to Rocca Bastion ${ }^{4}$

2 As illustrated by the first lines of the poem "Street Map of Nicosia" by Niki Marangou, Nicosia's territory shows that geographical division also marks the coexistence of different languages in Cyprus. The streets change names on each side of the Green Line, and the poem renders the linguistic barrier all the more tangible by including the different names in their original languages and alphabets as they appear on the street signs. Crossing over, however, which has been possible since 2003 with the opening of several checkpoints on the Green Line, does not only result in changing languages. The streets continue with different names, so mythological references on the Greek side, for instance, are not literally "translated" by the Turkish signs, which refer instead to the Ottoman past. The poem makes visible that crossing the border means entering a different narrative about the island's history.

In Cyprus, "language has been considered by the two major communities to be the primary proof of identification with the corresponding motherland, ${ }^{{ }_{5}^{5}}$ whether Greece or Turkey. According to the Greek version of the island's national narrative, Cyprus has been a Greek island since the settling of a Mycenaean population during the Bronze Age. According to the Turkish version, the island has been considered an Anatolian extension since its conquest by Ottoman troops in $1571 .{ }^{6}$ Yet the "cultures of nationalism" that remain strongly present in the island-accused of feeding the political and diplomatic dead-end of what has been coined as the "Cyprus problem"-have been challenged since the 1990s by scholars and writers working together from both sides of the Green Line. ${ }^{8}$ In the literary field, the challenge has often been specifically addressed through the matter of language and translation, as evidenced by a shift toward collective and multilingual publications. ${ }^{9}$ A great number of texts written by the new generation of poets and novelists circulate in Cyprus in more than one language, often in translations undertaken by fellow poets or, occasionally, by the authors themselves. ${ }^{10}$ These texts are equally available in their original and/or translated versions at the local level, and are quoted in journals and at cultural gatherings such as conferences, poetry readings, and exhibitions in both the original language and in translation, depending on the language proficiency of the audience or readership.

Niki Marangou (1948-2013) is considered one of the most important figures in the modern literature of Cyprus. She was an awarded poet, novelist, and artist. Even though she only wrote in Greek, her work reflects the issue of multilingualism and divergent narratives. ${ }^{11}$ Almost all her work exists in translation-mostly in English, to a lesser extent in Turkish, and in other languages. ${ }^{12}$ Towards the end of her literary activity she published several pieces that included translation(s) along with the original texts. These include "Nicossienses," a short essay about her recollections of the Cypriot capital that appeared as a book in the island's three languages, ${ }^{13}$ and a bilingual collection of poetry written between 2000 and 2013 that displays her poems in English translation on the left page and in the Greek original on the right. ${ }^{14}$

5 In addition to this consideration for inter-lingual translation, Niki Marangou also engaged in intra-lingual translation, as she comprehended the Greek language in its historical depth and geographical diversity. In an autobiographical profile she wrote: “To кEvтрıкó

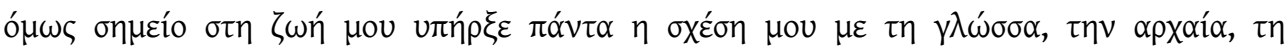

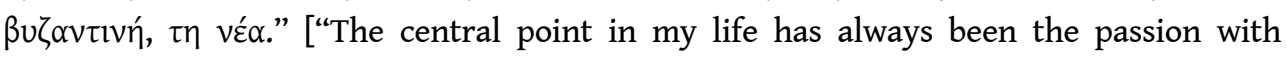
language, with the Greek language in all its forms, contemporary, ancient, Byzantine"]. ${ }^{15}$ 
She further explored language translatability by experimenting with its spoken and written forms. An example of this can be seen in the short story collection Eighteen Narratives, ${ }^{16}$ in which she gathers testimonies from eighteen elderly women who originated from all over Cyprus. Each testimony is written in the island's major vernacular, the Cypriot Greek dialect, which Marangou renders in different nuances according to the women's age, background, and region of origin. Besides creating the illusion that the stories are written as they would have been (orally) told, the book obviously plays on the many dimensions of the language, oral, written, vernacular, and standard. ${ }^{17}$

6 As illustrated by the poem "Street Map of Nicosia" quoted above, translation in Cyprus may be understood not merely as the transfer of a message into another linguistic system, but rather in terms of the philosophical paradigm coined by Paul Ricoeur: the dialogical process of transferring meaning into an explanatory narrative, one which negotiates Self and Other between and within languages. ${ }^{18}$ The mapping of the border that underlines the language barrier in the poem points to the different directions of translation. The narratives of Cyprus move apart on either side of the Green Line, and the street names, as Geek Cypriot poet Stephanos Stephanides writes, "test the boundaries of the mythic past which constructs our cultural memory." 19 But contemporary diversity only reflects heterogeneity within narrative itself, as shown by the last verses of the poem:

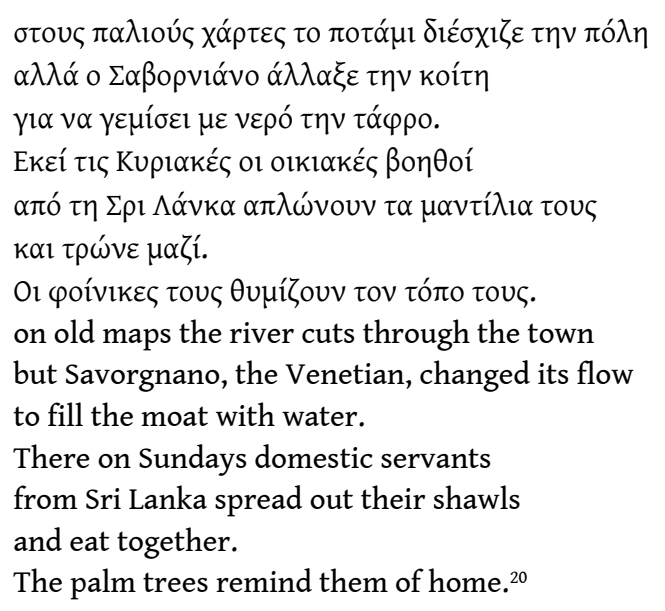

Contemplating the course of the Green Line, the poet is reminded of the old course of the river, which also used to cross Nicosia until the fortification of the medieval defensive walls in the Venetian era (1489-1571). This second course opens up another layer of signifying, which the poem accesses differently in Greek and in English: whereas the English translation specifies the provenance of Venetian engineer Savorgnano, the original in Greek does not mention it. The translation considers that an anglophone audience, whether Cypriot or foreign, might not be as aware of Cyprus's long history as a hellenophone public would, thus manifesting one of the many ways the poem-like a text in general-can reach its multiple readers. In the last verses, the poem overturns the excursion into the past and ends with the modern use of the ancient moats, transformed into public gardens when Cyprus was a British colony (1878-1960). There on weekends, new populations of immigrants ${ }^{21}$ gather today, and the palm trees-Cyprus's landscape mark-become significant for yet another understanding of home and self. ${ }^{22}$ The border, at the crossroads of language and cartography, visibly allows Niki Marangou to go far beyond the "Cyprus problem" and its restrictive views, as its mapping creates movement 
in historical depth and between narrative multiplicities. In this article, I argue that translation is key in Niki Marangou's work, as it constitutes a writing principle and conveys alternative perspectives that challenge political statements.

\section{The Voice of Many Voices}

8 One of the clues suggesting that Niki Marangou's work can be approached through translation is the apparent contradiction between the structural role of the first-person narrator, and the fact that she does not engage in self-writing. A general overview of Niki Marangou's work shows the great diversity of the genres she wrote in - she published several novels, essays, short stories, tales for children, testimonies, poetry collections, and even a cookbook. A prolific poet and prose writer, Niki Marangou would often combine different genres in her poetic prose and narrative poetry, oscillating between fiction and reality, personal memories and collected anecdotes. The continual appearance of the subject "I" suggests an adequacy of relation between author, narrator, and character when appropriate, and contributes consistency to her work in general, the only exception being perhaps in her tales for children. However, her work cannot be considered simply autobiographical. In Eighteen Narratives, for example, she describes her task as that of an editor:

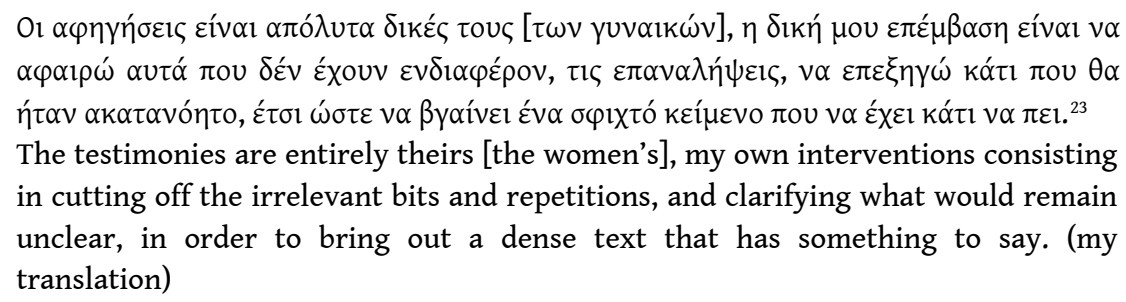

As the book consists of a testimony collection, the statement is indeed relevant. However, it expresses the general attitude of a narrator who often seems to disappear behind what she recounts, ${ }^{24}$ as her voice usually bears the voices of others.

For the most part, Niki Marangou's texts are concerned with places she visited herself, sometimes for a single stay and sometimes over many trips. While Cyprus was definitely the main subject of her inspiration, other places, including Egypt, Western Asia, and various Eastern European countries, were also frequently explored, both in writing and in real life..$^{25}$ In order to map her different journeys, Niki Marangou (and/or her narrator) would collect stories about the visited cities, towns, or villages according to a double process: she would gather testimonies heard in random conversations in the street or told by her friends, and she would inquire into the locations' specific histories as evidenced through antiques or items of any kind, spotted in shops, bazaars, flea markets, or historical monuments; the first-person narrators of her texts are often depicted wondering about the times and periods when these objects were still in use. The narrator herself draws on the comparison between people and objects as a resourceful impetus for

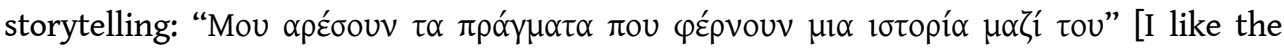
things that carry a story with them]. ${ }^{26}$ As such, the different texts about her traveling destinations-but also about Cyprus that was her home-consist of many embedded stories combining personal and non-personal recollections and experiences, reconstituting these locations in different layers of space and time:27

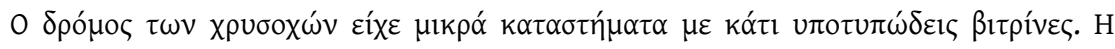

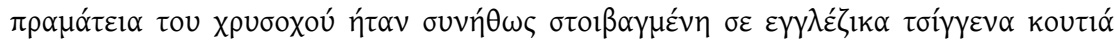




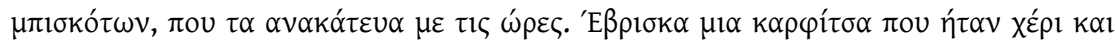

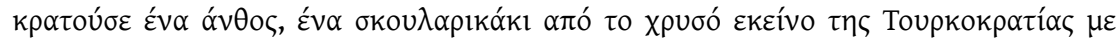

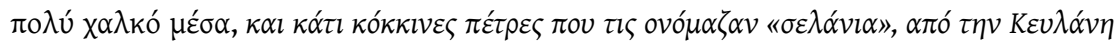

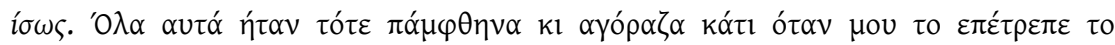

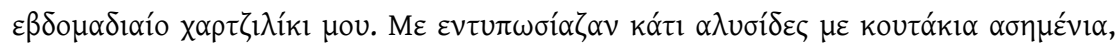

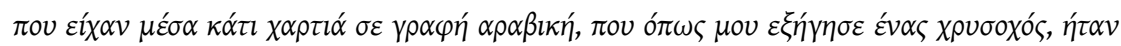

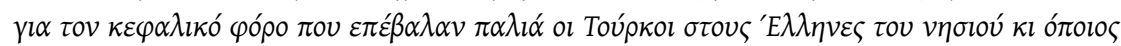

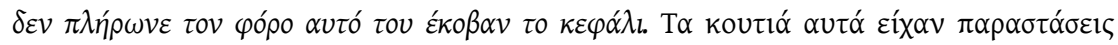

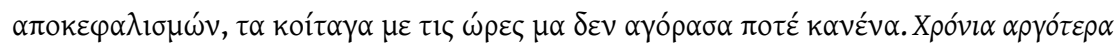

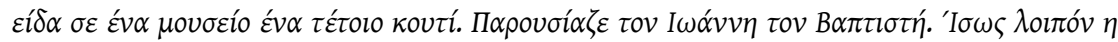

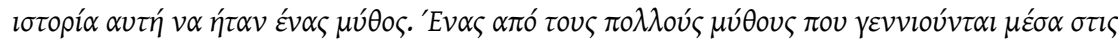

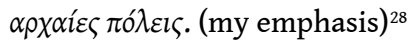

The road of the goldsmiths had tiny shops with rudimentary window displays. The merchandise was piled up inside English biscuit boxes, in which I rummaged for hours. I found a brooch in the shape of a hand holding a flower, a small earring of the red Ottoman gold made with a lot of copper, and a few red stones called 'Ceylania,' perhaps from Ceylon. Everything was very cheap then and, from time to time, I could afford to buy something with my weekly pocket money. I had been very impressed by small boxes on silver chains, which contained papers with Arabic inscriptions, and used to serve for the poll tax the Greeks of the island had to pay to the Turks-as a goldsmith explained to me. Whoever refused to pay the tax had his head cut off. I would stare at these boxes, engraved with representations of executions but I never bought one. Years later, I saw in a museum a similar box, representing John the Baptist. The story might have been just a myth then, one of all the numerous myths that are borne into ancient cities. 29

In this excerpt quoted in length from the essay "Nicossienses," Niki Marangou recalls her bargain-hunts as a teenager in the old town of Nicosia, in the early 1960s. The text opens up the city's temporality in various layers, using items as gates to the past-for example, the biscuit tins and the jewellery evoking the British presence in Cyprus or the Ottoman era. These objects may be said to translate the past, as they are bearers of diverse "myths" or stories, real or invented, such as the goldsmith's interpretation of the silver boxes or the Christian episode of the beheading of John the Baptist. The layers of time are of different natures: personal memory, recalling the time the narrator used to wander in the capital's old shops; collective memory, with the goldsmith's anecdote; and (official) history, evoked by the mention of the museum. Through her walks and recollections, the narrator activates insights into Nicosia's past, and her voice contains the many stories of

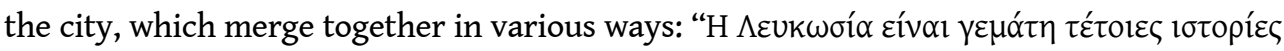

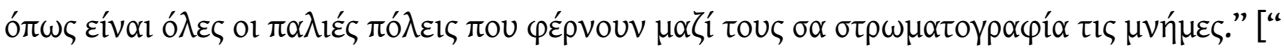
Nicosia is full of such stories, as are all old cities that carry with them layered memories." ${ }^{30}$ With an effect of mise en abyme, Nicosia is described in a way that echoes the structure of the text "Nicossienses": the geological metaphor in the original Greek

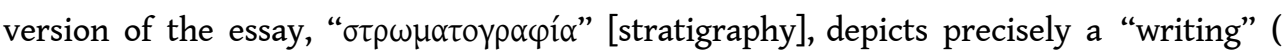
$\gamma \rho \alpha \varphi \eta ́ / g r a p h y)$ made of stories or memories in "layers" ( $\sigma \tau \rho \omega \omega \mu \alpha \tau \alpha / s t r a t a) .{ }^{31}$

The additions inserted when the text was updated in 2012-which I have shown in italics above-point out that new layers open up with the narrator's consideration for the meaning of "things," that is translation. Her wondering about the red stones' name in the colloquial language (“'Ceylania,' perhaps from Ceylon”) works as a reminder of Cyprus's location on the route to India, particularly during the colonial era. In the same fashion, the second addition, which provides more explanation about the silver boxes used for the poll tax, seems to be motivated by the remembrance of the "Arabic inscriptions" inside 
the boxes. Precisely because these letters are not immediately decipherable, and the boxes' purpose remains uncertain, the narrator needs interpretation, or translation. The text offers two possible versions: the goldsmith's explanation, sociological yet unsubstantiated, invoking the former Ottoman administration, and an alternative yet non-contradictory version at the museum, which includes the silver boxes in the aesthetic discourse of the history of art but does not provide information regarding their use. This excerpt can thus be read as an allegory of translation. The two explanations offer what Paul Ricœur has coined as an "equivalence without identity," ${ }^{32}$ or an equivalence that is not adhesion. As they each work on a different level, the two interpretations remain non-identical and can be compared with one another. For example, the narrator wonders whether the poll tax story is a fact or a legend, and proceeds, therefore, as a translator who negotiates meaning between two incomplete, questionable, yet plausible versions. ${ }^{33}$ By concluding that they both belong to Nicosia's greater memory, the narrator does not try to make further sense of them; she "advance [s] with some salvaging and some acceptance of loss" ${ }^{34}$ that is inherent to the process of translation. Yet by giving up finding the "truth" about the boxes, she brings out another interpretation from the space in between the alternatives.

Regardless of their differences, what the two interpretations do render is the violence contained in the symbol of execution, which the goldsmith specifies as the rupture between "Greeks" and "Turks." If we bear in mind that the essay describes postIndependence Nicosia, it is noteworthy that the first barricades in the capital-the roots of the future Green Line-are mentioned without any reference to the many outbreaks of violence from which they originated, to which the narrator was oblivious at the time: "

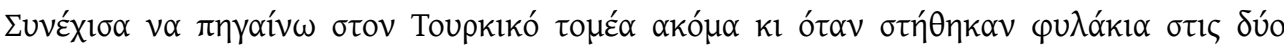

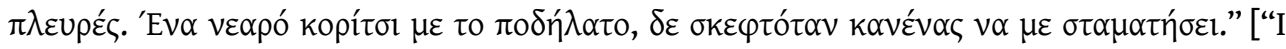
carried on going to the Turkish Quarter even when roadblocks were erected on both sides. As a young girl on a bike, no one thought of stopping me."] ${ }^{35}$ Moreover, the goldsmith's vocabulary is anachronistic since it refers to the modern idea of bi-national Cyprus, ${ }^{36}$ whereas during the Ottoman administration the (more than two) island's communities were identified by the religion they practiced, and all had to pay taxes. What the episode translates, thus, is the social, political, ideological, and epistemological shift that led to the many years of inter-communal violence preceding the Turkish invasion.

\section{The (Un)translatable and the Necessity to Translate}

14 The element of violence in the episode of the silver boxes is essential to understanding translation as a writing principle in Niki Marangou's work. It could be argued that the idea emanates from a generous and positive reading of her work through Paul Ricoeur's philosophical paradigm. In the essay "Nicossienses," the words "myths", "stories," and "memories" alternatively name the same thing, which suggests an ontological equivalence corresponding to the concept of narrative identity at the root of Paul Ricoeur's definition of translation: identity, or the sense of self and unity, is constituted through the narrative of the past and of experiences, and this narrative comes out in a different manner every time it is told. ${ }^{37}$ Niki Marangou's work illustrates narrative as the negotiation between Self and Other (both outside and within the Self), as "Nicossienses," for example, partially reconstitutes Nicosia's collective memory by integrating a variety 
of voices which are "other" to one another. Drawing an analogy with translation, we could further argue that the narrator reconstitutes Nicosia's living language, which she collects as many particular idioms of as she can. The text thus works as a translation in the sense of a paradigm of "linguistic hospitality:" ${ }^{38}$ the narrator "hosts" (hospes) "foreign" (hostis) voices within her own, without absorbing or neutralizing their otherness. ${ }^{39}$ In her article about divided Nicosia, Sherry Simon notes, however, that translation in Cyprus represents less a gesture of kindness than a social necessity. ${ }^{40}$ The capital, like all dual cities, makes visible the fact that the Other to address and to hear is not foreign or even distant; it is the citizen with whom we share the same place, town, sense of home, and daily life. Translation is therefore perceived as a movement across, and a displacement towards, different points of view; but decentring oneself is limited by the inherent knowledge that one's own narrative can always be challenged and/or weakened by another, at times incompatible, narrative. The element of violence in translation reminds us that the paradigm is not always the amiable idea of a hospitality everyone should adopt in order to avoid or resolve conflict, since it also shows the very limits of common ground. In other words, when understanding and reciprocity are endangered, translation makes visible the untranslatable.

An anecdote recounted twice by Niki Marangou appeared for the first time in a poem

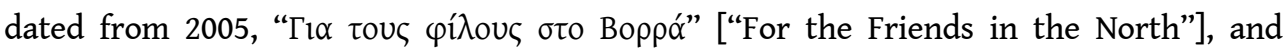
constitutes a digression in the 2010 novel $\Gamma \varepsilon \zeta$ oú $\lambda$ [Yezoul]. The episode narrates a visit to a village tavern in the Karpass peninsula-in the northern part of the island under Turkish occupation-where Niki Marangou recognizes a painting on the wall, which her own mother had made decades ago. The painting used to hang in her family house by the beach in Famagusta, which was lost as a result of the 1974 invasion. ${ }^{41}$ She tells the tavern owner about the painting, but he replies that he will not give it back as he considers it a war trophy. I quote the last verses of the 2005 poem:

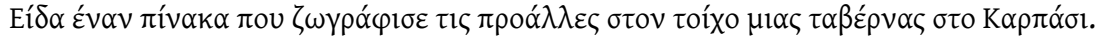

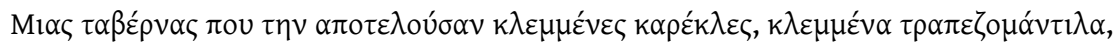

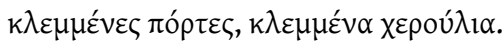

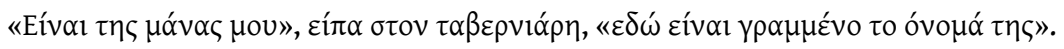

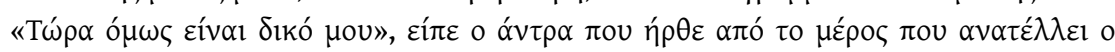

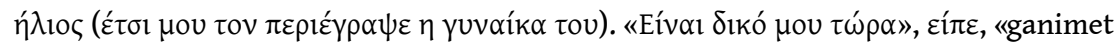

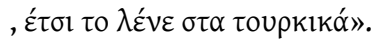

The other day, I saw one of her paintings

hanging on the wall of a tavern in the Karpass.

A tavern made up of stolen

chairs, stolen tablecloths, stolen

doors, stolen handles.

"It's my mother's," I told the innkeeper, "her name is written here."

"But now it's mine," said the man who came from where the sun rises (that's how his wife described him to me). "It's mine now," he said, "ganimet, is how they call it in Turkish." ${ }^{42}$

The subject "I" reports the event focusing, in order, on the painting, the list of stolen items from Famagusta, the origin of the innkeeper, and the untranslated Turkish word " ganimet." The painting works as a catalyst for the poet, who suddenly realizes that the cheap tavern furniture around her must also come from looted Famagusta-the repetitive use of the adjective " $k \lambda \varepsilon \mu \mu \varepsilon ́ v o \zeta$ " [stolen] marks this revelation. She understands that the innkeeper has a totally antagonistic narrative about the situation: he is a settler who was given a chance to make a new home in an area taken by his country's forces ${ }^{43}$ The poet 
does not show any active sign of rejection or aggressiveness, but the text significantly ends with the untranslated word "ganimet," as if to signify incompatibility, since what it names ("war loot" or "trophy") can only exist in Turkish in the Cypriot context. The word is pointed out as foreign and untranslatable, with the Latin characters in the Greek original, and with the italics in the translation.

The 2010 version of the same episode further develops the matter of untranslatability:

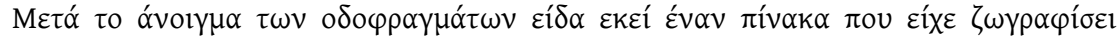

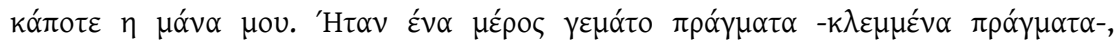

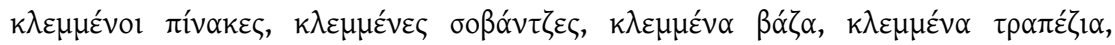

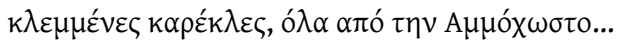

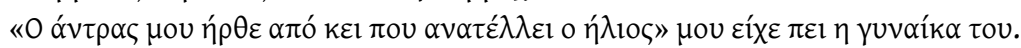

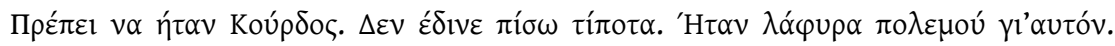

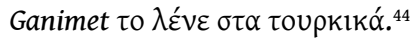

After the opening of the green line, I saw there a painting that my mother had once made. It was a place full of stuff-stolen stuff-stolen paintings, stolen stands, stolen vases, stolen tables, stolen chairs, everything from Famagusta.

"My husband came from where the sun rises," his wife told me.

He must have been Kurdish. He did not give anything back, because it was war loot. Ganimet, they say in Turkish. (my translation)

Published five years later, the episode is narrated in the exact same order. The most obvious variation however, is that the word "ganimet" is first translated ("war loot"), and then de-translated into its original form to insist on the narrative incompatibility. More subtly, the text in prose emphasizes with a quote another knot of untranslatability through the metaphor given by the innkeeper's wife about her husband's origin (Anatolia). In both texts, the poet/narrator apparently hosts or translates the woman's metaphor, as she quotes it without referring to the language she used to speak with the couple. However, the metaphor itself is a periphrasis that deconstructs the etymon at the root of the region's name in all languages ( $\alpha v \alpha \tau 0 \lambda \eta$, which literally means "sunrise" or

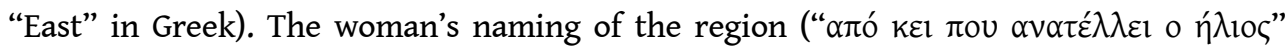
[from where the sun rises]) is therefore a translation, and yet it avoids naming what it

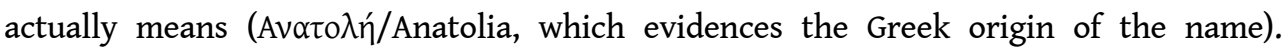
Precisely because it is translated, the periphrasis works as an untranslatable, or as a marker of incompatibility between conflicting narratives that the narrator herself quotes (un)translated. Jacques Derrida's word, about the translatable and the untranslatable being equivalent, ${ }^{45}$ is often understood as the positive process of meaning, as a translated signifier always loses something from its first extraction in order to be brought to a new sense or be renewed in the process of translation. ${ }^{46}$ Yet, the episode of the painting offers a compelling illustration of this concept of the (un)translatable, not in the positive sense in that it coins the natural process of signifying, but as a paradigm revealing knots of violence where mutual exchange and comprehension remain endangered. The text should not be read as an indirect rejection of an alternative narrative by the narrator, as she explicitly de-identifies with the Famagusta refugees' major claim, ${ }^{47}$ for whom reparation can only happen by getting back everything that was lost or taken: " $\Delta \varepsilon v \vee \dot{\eta} \theta \varepsilon \lambda \alpha$

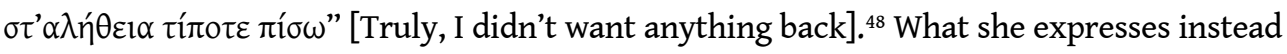
is an anxiety (“ $\tau \alpha \rho \alpha \chi \eta \eta^{\prime \prime 49}$ ) that urges her - in the novel - to learn more about loss itself. 


\section{All Vanishes}

19 In Marangou's 2010 novel Yezoul, the narrator's inquiry into collective memory - in this case, into Athens's past - is driven by the untranslatable. The novel offers indeed a space of reflection on translation, as it displays two narratives in one. The main narrative is a biographic novel that recounts, from a third-person perspective, the life of a $19^{\text {th }}$ century Athenian woman who attended the Greek revolution (1821) and the following decades of Greece's transformation into a modern nation-state. It is the fictionalized biography of Tereza Makri - nicknamed Loula in the novel - who was a minor historical character known as the "Maid of Athens" from Lord Byron's eponymous poem (1810). ${ }^{50}$ In the novel's first chapters, a secondary narrative in italics is inserted within the main story, consisting of a series of episodes depicting a first-person narrator discovering and settling in modern-day Athens. The first-person narrator is a Cypriot woman who recounts anecdotes - such as the episode of the painting quoted above - suggesting that she is the same narrator as in Niki Marangou's other pieces. In the same fashion described above, the first-person narrator unravels Athens's history by collecting stories/memories of its past, as she visits different areas at random, browses antique shops, meets new friends and neighbors, and goes to excursions or attends cultural events.

At first sight, the two narratives have nothing in common but the fact that they both take place in Athens. Yet the reader soon works out that the secondary narrative exposes the narrator's different discoveries that motivated the writing of the historical novel Loula's story, or Tereza Makri's fictionalized life:

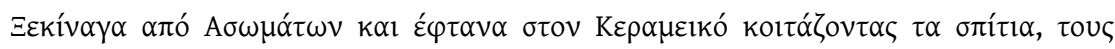

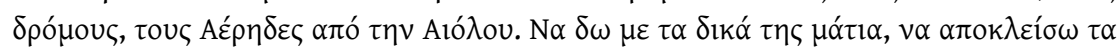

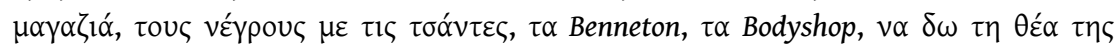

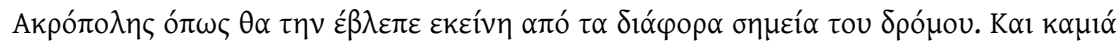

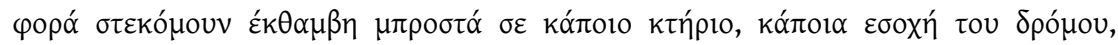

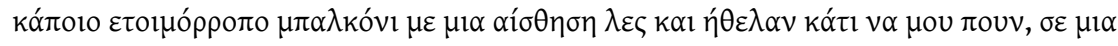

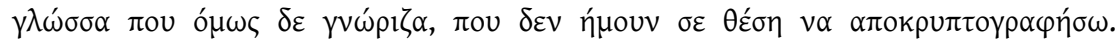

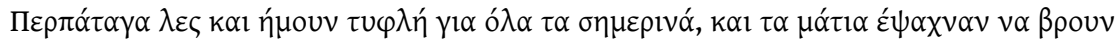

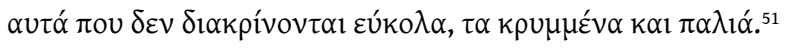

I would start from Agion Asomaton Street to reach the Kerameikos area, watching the buildings, the streets, the Tower of the Winds. So I could see through her eyes, ignoring the stores, the black men selling bags, the Benneton and the Bodyshop, admiring the view of the Acropolis as she would see it from the different parts of the street. And sometimes, I would stand dumbfounded in front of a building, a nook in a street, or a balcony ready to collapse, with the feeling that in a way, they had something to tell me, but in a language I didn't understand, that I wasn't able to decipher. I would walk as if blinded to modern things, my eyes looking for what you can't easily see-the hidden and the old. (my translation)

21 As she is depicted walking Athens's historical center, the narrator's method is explicitly compared to that of a translator: a process or an act of overcoming untranslatability. To quote her own words, the narrator tries to "decipher" a past "language" that, at first, "she does not understand." The inability to immediately read that language - or in this case, to hear it - urges her to go deeper in her investigation, looking for "the hidden and the old" around her; this strange drive or "desire to translate", to quote Antoine Berman's coinage, ${ }^{52}$ is expressed by the idiomatic expression " $\lambda \varepsilon \varsigma \kappa \alpha$ " [as if] repeated twice. As a translator who has first to understand the text to be interpreted, the narrator confronted 
with untranslatability - the undecipherable language she wants to understand - starts acting or interpreting the historical character that she wants to bring back from the past. Earlier in the first-person narrative, the narrator relates a strange encounter that took place in Cyprus before she even started to visit Athens: an old man then known as a mystic had told her that Tereza Makri was her own name in a previous life. The narrator disregarded this awkward revelation; however when she started to visit the Greek capital years later, she realized that she had bought a flat in the street where the Makri family used to live. She started then to investigate the character, but she could not find much about Tereza, as her existence has almost disappeared from archives or historical data. ${ }^{53}$

What the episode - the novel's secondary narrative in general - suggests is that to compensate for historical loss, the narrator must recreate the character she wants to give life to by incarnating her. In the excerpt quoted above, she pictures herself as Tereza, and Tereza as herself, while she walks Athens's old streets and "see[s] through her eyes" what she imagines Tereza did and saw. She becomes sensitive to insights and intuitions, unconsciously selecting what she sees or does. This interplay between narrator and character illustrates precisely what Walter Benjamin has described, in his 1923 essay, "The Task of the Translator," as a "mode" or "stage of... continuing life." ${ }^{44}$ Translation in this sense is a historical process that restores a text - an expression, or an experience which may be out-dated or no longer understood into the present of a new language, which in turn transforms or renews the original expression. ${ }^{55}$ For the translation to be successful, the translator has "to find the intention toward the language into which the work is to be translated, on the basis of which an echo of the original can be awakened in it." ${ }^{56}$ In this regard, it is compelling that the narrator translates Tereza's biography as she enacts the character "with completely unmetaphorical objectivity," ${ }^{57}$ and looks for her "intention" in her own body, as shown by the lexical field of sight. She then composes Loula's story, which is Tereza's renewed life (its translation) interpreted by the narrator's "language" - i.e. with her personality, experience, knowledge, and imagination. The transitions between the two plots underline indeed the emotional and physical connections between the narrator and her character. For example, when teenage Loula

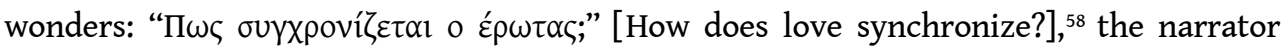

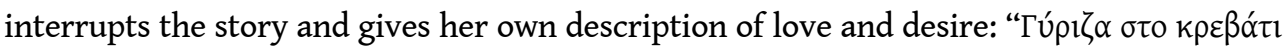

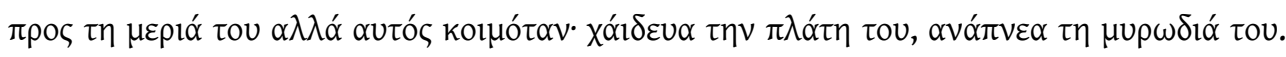
Eutuxía." [I turned over to his side of the bed but he was asleep; I touched his back and breathed his scent. Bliss]. ${ }^{59}$

The narrator, the historical figure, and the fictionalized character make visible the paradigm of translation in the novel. Loula's story stands as a reconstitution or continuation of Tereza's life in the $19^{\text {th }}$ century, based on what the narrator has been able to discover and has chosen to imagine about Athens at the time. The novel gives Tereza a plausible and renewed life experience, focused on inner feelings and emotions-among others, desire, depression, and maternal love. ${ }^{60}$ Moreover, it shows that untranslatability (historical loss) is actually key to creation, as loss is to gain.

The novel's title is in fact a(n) (un)translated word. After the narrator has bought her flat in Athens and is getting familiar with the city, she becomes friends with Vasilis, who owns an antique shop near her flat. One day he invites her over for coffee:

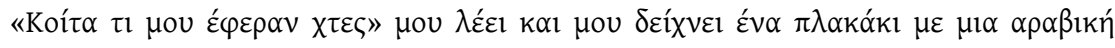

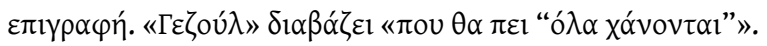

«All vanishes» $\varepsilon \pi \alpha v \alpha \lambda \alpha \mu \beta \alpha ́ v \omega \mu \eta \chi \alpha v \imath \kappa \alpha ́$. 


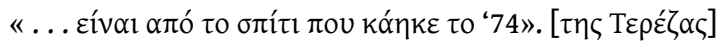

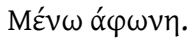

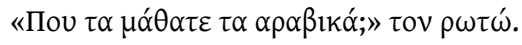

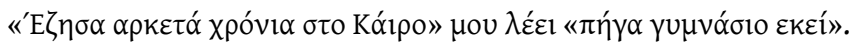

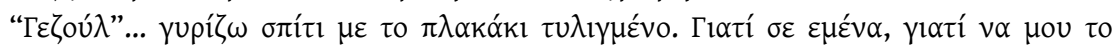

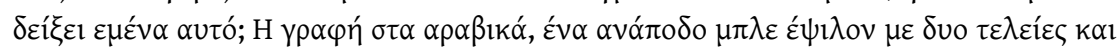

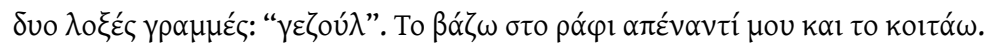

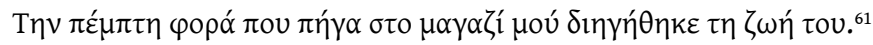

"Look what they brought me yesterday," he says and he shows me a tile with an inscription in Arabic. "Yezoul," he reads, "which means "everything disappears."

"All vanishes," I say automatically.

“... It is from the house that burnt in 1974." [Tereza's house]

I am speechless.

"Where did you learn Arabic?" I ask him.

"I lived many years in Cairo," he answers. "I went to school there."

"Yezoul"... I go home with the tile wrapped in paper. Why me, why would he show it to me? The Arabic word: a reversed blue epsilon, with two dots, and two slanted letters. "Yezoul." I put the tile on a shelf in front of me and I observe it.

The fifth time I went to Vasilis' shop, he told me the story of his life. (my translation)

The only actual remnant from Tereza Makri's house is explicitly associated with translation. The Greek original emphasizes even more the movement of translation with the adjacency of three languages. The narrator first writes (in Greek) the Arabic word on

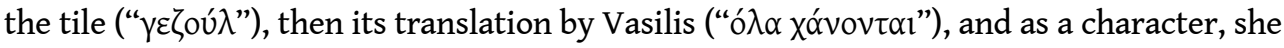
then translates it herself into English ("all vanishes") - even if the plot does not justify it since the conversation is happening in Greek. Further down, the narrator goes on describing the word she cannot read by partially applying an alphabet she knows: in her eyes, the first two letters of the Arabic word ( $s$ and $j$ ) appear as an inverted Greek epsilon $(\varepsilon)$, but the other two letters remain undecipherable $g$ and It is also $(J$ noteworthy that she decrypts the word from right to left as she would do if she could actually read it. The word is literally untranslatable for the narrator who does not know the language; moreover, it seems out of any context since the tile on which it is written makes no sense for her. Vasilis, who can read Arabic, is yet not able to provide further information about the tile's use or provenance - other than that it was found in Tereza's old house. The narrator keeps repeating "yezoul" as she observes the tile she will know nothing about, and that will be of no consequence for Loula's story even though it gives the novel its title.

The excerpt offers a vivid illustration of Walter Benjamin's concept of "pure language" as an achievement of translation: "pure language" (or "pure intention") is the essence proper to a literary work of art, which translation is supposed to reveal by means of the new version or language given to the work. ${ }^{62}$ The metaphor given by Walter Benjamin to conceive the idea is that of a broken vessel, the original text and its translations consisting each in a different fragment which allow the reader to seize - even partially the work's pure intention. ${ }^{63}$ In this manner, when pure language reveals itself, the sum of all texts (original and translations) disappear:

In this pure language - which no longer signifies or expresses anything but rather, as the expressionless and creative word that is the intended object of every language - all communication, all meaning, and all intention arrive at a level where they are destined to be extinguished. ${ }^{64}$ 
because of its meaning and of its materiality, the tile "yezoul" represents such a fragment, in Marangou's novel and in her work in general. With the dynamic of

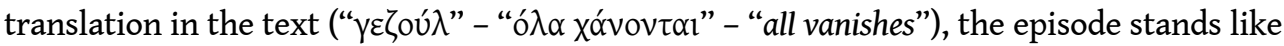
an epiphany wherein the narrator glimpses and names the natural movement of life, as the passage between and within language(s) seizes the passing of time and the fact that nothing remains the same in the continuum of creation. She seems to unconsciously fathom the nature of her own work, which captures people's lives and experiences on their way to extinction and tells them anew by means of her own stories. What is more, she acknowledges loss and extinction as a means for writing or creating, which explicitly appoints writing as translating.

\section{Concluding Remarks}

I would like to conclude my discussion with a few remarks that the episode of the tile brings out. Perhaps paradoxically, the novel takes its title from an object the narrator is not able to figure out, and which does not even appear in Loula's story. What it does in the novel's global economy, however, is mark a transition in the first-person narrative: a new digression opens up that takes the narrator away from Athens, as she follows Vasilis's account about his childhood in Egypt, and then his half-sister's testimony about Cyprus during the interwar years. After this long digression, the first-person narrative ends and the main story is not interrupted anymore - only a few paragraphs in italics appear in further chapters. The passage in translation creates a definite shift in the novel, as the narrator moves away from Athens whereas the main plot stays centered on the Greek capital - with a few excursions into other cities and islands, such as Missolonghi, Aegina, Corfu, Istanbul, and Saint Petersburg.

What this shift first marks is the novel's rupture between history and literature as a way to convey an alternative point of view regarding a supposedly known historical period. Indeed, Marangou chose a historical figure that allows her to trigger history without eluding the literary (fictitious) nature of her work. The book, subtitled "novel" on its very first page, is a fiction based on true events - it is Loula's story, which differs slightly from Tereza Makri's historical life. ${ }^{65}$ The idea of literature as a means to explore history is evoked by an episode in which the first-person narrator recounts a part of her research on $19^{\text {th }}$ century Athens: as she is reading a biography of Lord Elgin, ${ }^{66}$ she is suddenly interrupted by the thought of his wife and what she could possibly have seen or lived in the epoch the narrator is fascinated about. Lord Elgin's wife lived through the period, yet she did not play any active part in it - at least not that history has remembered - and in this regard, Loula's story stands as a plausible account of the experiences an ordinary person may have had during a particular historical time at different stages of her life. The novel does not use the general tone of official history but stays focused on an intimate narrative. The shift between the two plots renders the movement of fiction that frees itself from historical reality in order to offer a different perspective on it.

This first understanding is made more subversive if we bear in mind that the shift is created by an episode in translation. The novel's background depicts the transformation of Greece from an Ottoman province into a newly constituted nation-state, and that of Athens into a state capital. In this context, the very choice of Tereza Makri as main character seems equivocal, since even if she existed in real life, Tereza Makri is above all 
Lord Byron's "Maid of Athens," mainly known today through his biography (Byron rented a room in her mother's house when he first visited Athens in 1809, and composed poems about her and her teenage sisters). ${ }^{67}$ As is known, the English poet played an important part in the Greek independence - at least in its representation-being one of the most famous Philhellenes who contributed to the intellectual, literary, and artistic movement of Greece's national regeneration. ${ }^{68}$ It is true that the novel does not address the matter of Greek nationalism, as politics remains in the background, but it explicitly overturns the hierarchical relationship between Byron and Tereza Makri, as an "English man" merely appears a couple of times during Loula's teenage years, with no name and without much importance for the rest of the story. Loula's story is thus completely freed from the usual narrative centered on Lord Byron, who is a minor character in the novel rather than the national figure he usually represents in the English literary canon and in the modern movement of Hellenism or Philhellenism.

The secondary narrative that illustrates the writing's process as a paradigm of hospitality also does not acknowledge this intellectual movement at the root of the Greek nation, since in the variety of her explorations, the narrator-translator never refers in any way to the myth of Athens or raises the stereotypes relating Greece to antiquity. In spite of the plurality of voices she carries within her own, the narrator stays within the scope of orally transmitted narratives and family chronicles, and she passes on living memories that at no time evoke the Greek nation idea or ideology. What is more, the language element in the (un)translatable - the mention of Arabic, which opens up the digression on Vasilis's life and its narrative sequels - actually leads the narrator to other areas, some as important as Athens to Greek culture and modern Hellenism: Istanbul, Egypt, and even Cyprus, to name a few. ${ }^{69}$ Vasilis's story itself starts in Athens, since he was born on the very street on which the narrator met him, yet it is entirely located elsewhere; in the same fashion, Loula's story starts in and constantly returns to Athens, even though she follows her husband's activities throughout the country all his life, as the wife of a British officer and representative at the newly constituted Greek government. The principle of translation therefore makes visible the novel's paradoxical dynamic that keeps Athens as the narrative's main axis and as the narrator's main field of investigation, all the while challenging the central role of the capital, or even continental Greece, in the hegemonic narrative that gives it a dominant position. The novel epitomizes the definition Emily Apter gave of translation's function:

as an act of disruption, translation becomes a means of repositioning the subject in the world and in history; a means of rendering self-knowledge foreign to itself; a way of denaturalizing citizens, taking then out of the comfort zone of national space, daily ritual, and pre-given domestic arrangements... Translation is a significant medium of subject re-formation and political change..$^{70}$

In my discussion of Niki Marangou's work, I have attempted to show how translation as mediation across languages, places and spaces informs the poetics of her writing, continuously probing questions of cultural and historical memory. 


\section{NOTES}

1. This article is a revised version of the conference paper "The Lives of Others in the Writing of Niki Marangou: A Paradigm of Translation," presented at the Tenth IABA World Conference "Excavating Lives," International Auto/Biography Association, University of Cyprus, 26-29 May 2016.

2. Among the many sources regarding the 1974 events, see for example Rebecca Bryant, Imagining the Modern: The Cultures of Nationalism in Cyprus, London/New York, I. B. Tauris, 2004, particularly her introduction.

3. Irini Savvides, "Cypriot Women Poets Cross the Line," Kunapipi: Journal of Postcolonial Writing \& Culture, vol. XXXIII, n 1-2, 2011, p. 106-107.

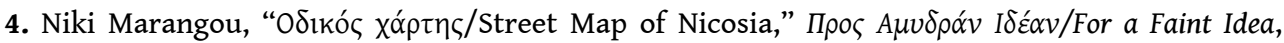
bilingual edition, translated from the Greek by Xenia Andreou, Athens, Rodakio, 2013, p. 12-13.

5. Marios Vasiliou, "Cypriot English Literature: A Stranger at the Feast Locally and Globally," Kunapipi: Journal of Postcolonial Writing \& Culture, vol. XXXIII, n 1-2, 2011, p. 84.

6. See, for example, the introductions to these volumes: Yiannis Papadakis and Rebecca Bryant (eds.), Cyprus and the Politics of Memory: History, Community and Conflict, London/New York, I.B. Tauris, 2012; and Yiannis Papadakis, Nicos Peristianis, and Gisela Welz (eds.), Divided Cyprus: Modernity, History and an Island in Conflict, Bloomington/Indianapolis, Indiana University Press, 2006.

7. Rebecca Bryant, Imagining the Modern: The Cultures of Nationalism in Cyprus, op. cit.

8. Before the opening of the Green Line in 2003, Cypriot academics and writers would meet abroad. For example, one of the first collective volumes challenging the "Cyprus problem" from all fields of the humanities - Vangelis Calotychos (ed.), Cyprus and its People, Nation, Identity, and Experience in an Unimaginable Community, 1855-1997, Westview Press, Boulder CO, 1998-gathers the communications read at the interdisciplinary conference "Cyprus and Its People: New Interdisciplinary Perspectives" (Harvard University, 1994). Another collective volume addressing more specifically the question of language and literature - Mehmet Yaşin (ed.), StepMothertongue, From Nationalism to Multiculturalism: Literatures of Cyprus, Greece and Turkey, Middlesex University Press, London, 2000-gathers articles and poems read at the conference "From Nationalism to Multi-culturalism: New Interpretations in the Literatures of Cyprus, Greece and Turkey," Middlesex University, 1997.

9. The academic journal Cadences: A Journal of Literature and the Arts in Cyprus, which started in 2003 , is the most representative of this new type of publication, as it issues yearly creative writings in the many languages of the island. The 2011 issue of Kunapipi: Journal of Postcolonial Writing \& Culture, vol. XXXIII, $n^{\circ} 1-2$, was also dedicated to Cypriot literature of all communities and gathered both academic and creative writings. Earlier, a short anthology of Cypriot literature in Greek, Turkish, English, and Armenian appeared in the collective volume Step-Mothertongue edited by Mehmet Yaşin (op. cit., 2000). We can also refer to two poetry anthologies published in

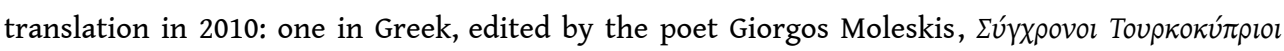

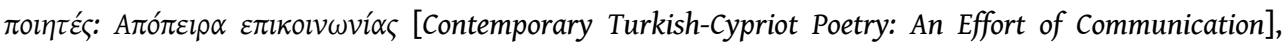
Athens, Topos Publications, 2010; and one in Turkish, edited by the poet Gürgenç Korkmazel, Kibrishrum S:-iir Antolojisi [Cypriot Poetry Anthology], Istanbul, Paloma, 2010.

10. Stephanos Stephanides, "An Island in Translation," Kunapipi: Journal of Postcolonial Writing \& Culture, vol. XXXIII, n 1-2, 2011, p. 51. 
11. It can be noted that Niki Marangou had some experience as a translator, as she translated

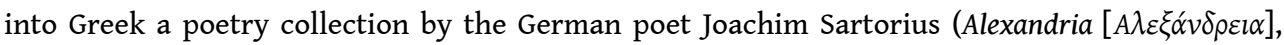
Athens, Rodakio, 1999).

12. The main translators of her work into English are Xenia Andreou, and the poet and scholar Stephanos Stephanides.

13. Niki Marangou, "Nicossienses," Photographies by Arunas Baltenas, translations by Xenia Andreou, Stephanos Stephanides, Murat Bülbülcü, Tuncer Bağișkan, Vilnius, Paknio Ieidykla, 2006. The essay is available in English on the author's blog, http://www.marangou.com/ nicossienses/, which also includes a revised version in Greek (updated in 2012), http:// www.marangou.com/nicossiensis/

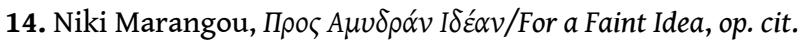

15. Niki Marangou, Cyprus PEN Literary Profile, $n^{\circ} 50$, Nicosia, 2009, p. 9; the text can also be found on the author's blog in English, http://www.marangou.com/biography/, and in Greek, http://

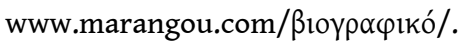

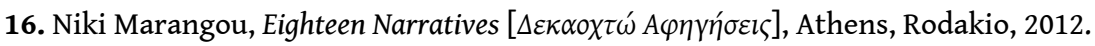

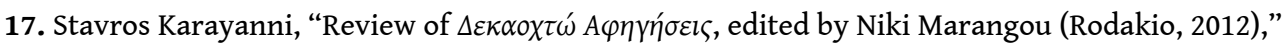
Cadences, vol. 8, fall 2012, p. 113.

18. Paul Ricœur, "The Paradigm of Translation," On Translation, translated by Eileen Brennan with an introduction by Richard Kearney, London/New York, Routledge, 2006, p. 11-29. The point will be further developed in my analysis.

19. Stephanos Stephanides, "An Island in Translation," op. cit., p. 50; in his analysis of the poem, Stephanides points out that the very names in the Turkish alphabet also carry another narrative by themselves: at the time of the Ottoman characters the streets refer to, the names would have been written with Arabic letters, as the writing of Turkish in the Latin alphabet only goes back to the language revolution implemented by Mustafa Kemal in the 1920s-who founded modern Turkey by distinguishing it from its Ottoman and Islamic past. The names in Turkish mark, therefore, the ideological and epistemological shift on which Turkish nationalism was founded (Stephanos Stephanides, idem).

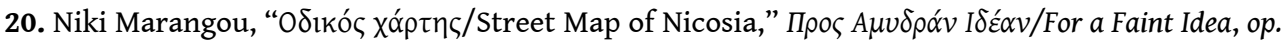
cit., p. 12-13.

21. Since the Republic of Cyprus became a member-state of the EU in 2003, migrant workers, female for the most part, have settled in the southern side of Cyprus, fleeing poverty from southern and eastern Asian countries (Irini Savvides, "Cypriot Women Poets Cross the Line," op. cit., p. 121).

22. Stavros Karayanni identifies the gardens as an "epistemological space" of "recreation." See "Migrant Goddess: Displacement, Gender and Transformation in Literature from Cyprus," in Geetha Ganapathy-Doré and Helga Ramse-Kurz (eds.), On the Move: The Journey of Refugees in New Literatures in English, Cambridge, Cambridge Scholars Publishing, 2012, p. 71.

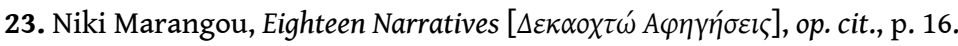

24. The poet's discretion is also evoked by Stavros Karayanni who notes, about her poem "Street Map of Nicosia," quoted in the introduction of this paper, that "the verse resists metaphorical embellishment as much as possible" so that the streets themselves bring out the city's multidimensional temporality ("Migrant Goddess: Displacement, Gender and Transformation in Literature from Cyprus", op. cit., p. 70).

25. On the importance of traveling for her poetic inspiration, see Frangiski Ambatzopoulou's

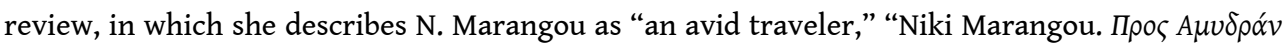
I $\delta \varepsilon \alpha v$, Rodakio, Athens 2013 [review]," In Focus Magazine, vol. 11, no. 2, June 2014, https:// cyprusinfocus.org/essay/niki-marangou/

26. Niki Marangou, $\Gamma \varepsilon \zeta$ oú [Yezoul], Athens, Hestia Publications, 2010, p. 54 (my translation). 
27. Among other sources, the plurality of temporalities in Niki Marangou's work has been raised by Sia Anagnostopoulou in her paper "The different temporalities of Cyprus in the work of Niki Marangou," read at the conference "Cyprus, Female Voice and Memory: Literature, Arts and History in the Work of Niki Marangou" (British School at Athens, Greece, 23/09/2017), https:// www.bsa.ac.uk/index.php/33-featured-news/337-cyprus-female-voice-and-memory

28. I quote here the revised version of "Nicossienses" from 2012, available on the author's blog, http://www.marangou.com/nicossiensis/

29. As I am referring to the revised version of the text in Greek, I quote the English translation by Xenia Andreou ("Nicossienses," 2006, op.cit., http://www.marangou.com/nicossienses/), to which I added in italics the modifications brought in 2012. They are therefore my translation.

30. Niki Marangou, “Nicossienses, " 2006, op. cit., p. 45, http://www.marangou.com/nicossiensis/ [Greek]; p. 29, http://www.marangou.com/nicossienses/ [English].

31. To illustrate this writing technique, a parallel could be drawn with Niki Marangou's artwork, as a common theme in her paintings represents the traditional Mediterranean louvered shutters, which combine at least two views-indoors and outdoors-in a single picture. See her website, http://www.marangou.com/gallery/paintings/

32. Paul Ricœur, "The Paradigm of Translation," op. cit., p. 22.

33. The equivalence translation offers is further analyzed by Paul Ricœur as a space enabling comparison ("construction of the comparable"), in "A 'passage': translating the untranslatable," On Translation, op. cit., p. 37.

34. Paul Ricœur, "Translation as challenge and source of happiness," On Translation, op. cit., p. 3.

35. Niki Marangou, "Nicossienses," 2006, op. cit., p. 40, http://www.marangou.com/nicossiensis/ [Greek]; p. 24, http://www.marangou.com/nicossienses/ [English].

36. In the introduction of her study Imagining the Modern, Rebecca Bryant describes how modernity encountered during British colonialism transformed "Muslims and Christians in Cyprus ... into Turks and Greeks" (op. cit., p. 2).

37. The concept of narrative identity has notably been developed by Paul Ricœur in Oneself as Another, translated by Kathleen Blamey, Chicago, University of Chicago Press, 1992, chap. 5 and 6; for further analyses of his concept, see, for example, Joseph Dunne, "Beyond Sovereignty and Deconstruction: The Storied Self," in Richard Kearney (ed.), Paul Ricour. The Hermeneutics of Action , London/Thousand Oaks/New Delhi, Sage Publications, 1996, p. 137-157; and David Rasmussen, "Rethinking Subjectivity: Narrative Identity and the Self," in Richard Kearney (ed.), Paul Ricour: The Hermeneutics of Action, op. cit., p. 159-172.

38. Paul Ricœur, "The Paradigm of Translation," op. cit., p. 23.

39. An extended analysis of the concept of "hospitality" is provided by Richard Kearney in "Paul Ricœur and the Hermeneutics of Translation," Research in Phenomenology, vol. 37, 2007, p. 151.

40. Sherry Simon, “À l'enseigne d'Hermès. La ville multiple à l'intersection des langues et des mémoires" (in French), in Maroussia Ahmed, Corinne Alexandre-Garner, Nicholas Serruys, et al. (eds.), Migrations/Translations, Paris, Paris Ouest University Press, p. 63.

41. The touristic area of Varosha, on the coastal side of Famagusta, was seized and looted by the Turkish army in 1974. Since then it has remained a forbidden zone, known as the "Ghost Town" of Famagusta.

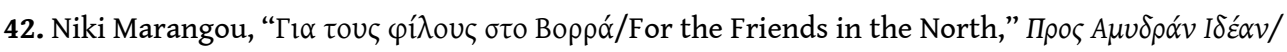
For a Faint Idea, op. cit., p. 14 [English] and 17 [Greek].

43. To compensate the depopulation caused by the Greek Cypriots' flight to the south of the Green Line after the invasion, thousands of impoverished Turkish settlers have been imported to the northern part of the island. It is estimated that they outnumber the Turkish Cypriot population today (Stephanos Stephanides, “An Island in Translation," op. cit., p. 47).

44. Niki Marangou, Yezoul, op. cit., p. 26. 
45. "[Nothing] can ever be untranslatable - or, moreover, translatable:" among other sources, see Jacques Derrida, "What is a 'relevant' translation?," in Lawrence Venuti (ed.), The Translation Studies Reader [Third edition], London/New York, Routledge, 2012, p. 369.

46. I would like to add that I owe the idea of translation as a negative paradigm-which can host and sometimes hide a situation of conflict and violence - to Tiphaine Samoyault in her conference paper "Traduction et violence" (in French), read at the seminar "Le comparatisme comme approche critique," Paris-Sorbonne Home for Research, 15/01/2016, https://www.canalu.tv/video/universite_paris_sorbonne/traduction_et_violence.20454.

47. The Famagusta refugees being the major part of the Greek Cypriot population evicted from the north in 1974, the return of Varosha constitutes a crucial element in the negotiations to solve the "Cyprus problem." See for example the newspaper articles by Elias Hazou, "Former residents eying return to Varosha homes," Cyprus Mail, 02/04/2017, http://cyprus-mail.com/2017/04/02/ former-residents-eyeing-return-varosha-homes/ and Evie Androu, "Turks will allow 16,000 refugees back into Varosha," Cyprus Mail, 24/07/2017, http://cyprus-mail.com/2017/07/24/ turks-will-allow-16000-refugees-back-varosha-reports/

48. Niki Marangou, Yezoul, op. cit., p. 27 (my translation).

49. Niki Marangou, idem.

50. The poem can be found in many anthologies or poetry collections; see for example Lord Byron (George Gordon), "Maid of Athens," The Poetical Works of Lord Byron, London, Oxford University Press, 1952, p. 60.

51. Niki Marangou, Yezoul, op. cit., p. 23-24.

52. Antoine Berman, "Translation and the Trials of the Foreign," in Lawrence Venuti (ed.), The Translation Studies Reader [Third edition], op. cit., p. 242.

53. My own research confirmed the limited sources about the character; some information is

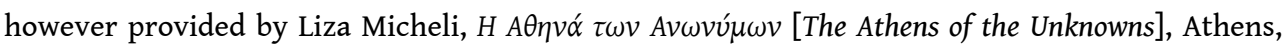
Patakis Publications, 1990, entry “Tereza Makri” p. 153-155 (in Greek).

54. Walter Benjamin, “The Translator's Task," translated by Steven Rendall, TTR: traduction, terminologie, rédaction, vol. 10, no. 2, 1997, p. 153.

55. Walter Benjamin, op. cit., p. 153-155.

56. Walter Benjamin, op. cit., p. 159.

57. Walter Benjamin, op. cit., p. 153.

58. Niki Marangou, Yezoul, op. cit., p. 24 (my translation).

59. Niki Marangou, idem.

60. The story's plausibility is in a way confirmed by a page on Tereza Makri recently published on Wikipedia, quoting Niki Marangou's novel as a biographical reference, https://el.wikipedia.org/

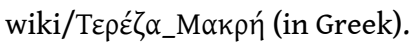

61. Niki Marangou, Yezoul, op. cit., p. 28.

62. Walter Benjamin, op. cit., p. 162.

63. Walter Benjamin, op. cit., p. 161.

64. Walter Benjamin, op. cit., p. 162-163.

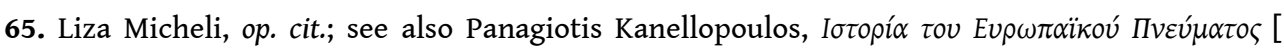
History of the European Spirit], part 4, vol. 9, Athens, Giallelis Edition, 1976, p. 363-371 (in Greek).

66. Lord Elgin was an English diplomat who is mainly known for his loot of the Acropolis' major masterpieces from the Parthenon, among other monuments.

67. Panagiotis Kanellopoulos, op. cit., p. 362-363.

68. Among many references, one can refer to David Roessel, In Byron's Shadow: Modern Greece in the English and American Imagination, Oxford, Oxford University Press, 2001; and Olga Augustinos, French Odysseys: Greece in French Travel Writing from the Renaissance to the Romantic Era, Baltimore, John Hopkins University Press, 1994. 
69. Stéphane Sawas considers Athens's struggle to impose itself as main cultural center after the independence in "Les expressions littéraires des diasporas grecques : une marge de la littérature néo-hellénique ?" (in French), in Corinne Alexandre-Garner (ed.), Frontières, Marges et Confins, Nanterre, Presses Universitaires de Paris 10, 2008, p. 51-63; Anna Olvia Jacovides-Andrieu points toward Cyprus' intermediary role at the turn of the $20^{\text {th }}$ century between Hellenism main cultural centers (Athens, Constantinople, Smyrna, and mostly Alexandria), in "Esquisse diachronique : La littérature chypriote de l'Antiquité à nos jours" (in French), in Josette Doron and Anna Olvia Jacovides-Andrieu (eds.), Prose et poésie chypriotes, VII siècle av. J.C.-XX ${ }^{e}$ siècle, bilingual anthology (French-Greek), Paris, Hellinika Chronika, Association des Amis de la Grèce, 1993, p. 43-44.

70. Emily Apter, The Translation Zone: A New Comparative Literature, Princeton/Oxford, Princeton University Press, 2006, p. 6.

\section{ABSTRACTS}

This article examines the work of Niki Marangou, a Greek-language author from Cyprus. Her many stories and anecdotes, whether in poetry or prose, bring in a perspective of cultural geography as they open up places to a spatial imaginary on the crossroad of cartography and testimony. Conceptual tools developed in the field of contemporary Translation Studies may be used to articulate fresh and interesting views on the historical, cultural, political, and ideological contexts of her work, and show the cross-cultural literary dynamic in which her writing emerges.

\section{AUTHOR}

\section{MARINE MEUNIER}

Marine Meunier is currently a joint Ph.D. candidate in Comparative Literature at the University of Cyprus (Department of French and European Studies) and at Saint-Joseph University of Beirut (Department of Letters). She is writing a thesis on contemporary literatures from the Near East (Cyprus, Lebanon, Israel/Palestine) in the broader theoretical field of World Literature. 